\title{
Modelling of Bioremediation of Oil-Contaminated Soil Using Chicken Droppings as Biostimulant
}

\author{
UWADIAE, SE; OBASI, CD
}

\author{
Department of Chemical Engineering, University of Benin, PMB 1154, Benin City, Nigeria \\ *Corresponding Author Email: sylvester.uwadiae@uniben.edu
}

\begin{abstract}
The suitability of poultry droppings as a biostimulant for the remediation of crude oilcontaminated soil has been investigated. Four equal-sized containers, each containing $400 \mathrm{~g}$ of soil were each contaminated $20 \mathrm{ml}$ of crude oil after which they were thoroughly mixed. To first three containers, A,B and C were respectively added $20 \mathrm{~g}, 60$ and $100 \mathrm{~g}$ of poultry droppings which were previously dried and pulverised. To the fourth container which served as control, was added no poultry droppings. The degradation of oil in the samples were monitored for 7 weeks by observing the residual hydrocarbon content (RHC) and $\mathrm{pH}$ of samples. The RHC of the samples over the seven-week period were then modelled using artificial neural network (ANN) in the MATLAB Neural Network Toolbox. The RHC values decreased for all samples, with the highest reduction of $100 \mathrm{mg} / \mathrm{kg}$ obtained in sample C and the least reduction of $1000 \mathrm{mg} / \mathrm{kg}$ in sample D. The PH values were observed to increase slightly from the acidic region of 5.5 to a range of 7.8 to 8.3 . The best and most suitable training algorithm of RHC of the samples was TRAINSCG since it had the least mean square error (MSE) value of 0.00183 as well as the highest R-squared value of 0.99808 .
\end{abstract}

DOI: https://dx.doi.org/10.4314/jasem.v25i11.7

Copyright: Copyright (C) 2021 Uwadiae and Obasi. This is an open access article distributed under the Creative Commons Attribution License (CCL), which permits unrestricted use, distribution, and reproduction in any medium, provided the original work is properly cited.

Dates: Received: 22 August 2021; Revised: 17 September 2021; Accepted: 06 October 2021

Keywords: Crude oil, RHC, ANN, Pollution, Optimization.

Due to the high demand for petroleum products in the society today, the petroleum industry activities have increased enormously, resulting some times in the undesirable occurrence of oil spills especially in oil producing countries such as Nigeria (Adams et al., 2015; Albert et al., 2018). Oil spills in soils are unwanted as they adversely affect the functioning of natural processes, disturb agricultural activities and result in economic growth drawback and production of undesirable environmental and health effects (Prasad and Anuprakash, 2016).On account of the highlighted adverse effect of oil spill on soil, there is therefore need to decontaminate it. The methods used for remediation of polluted soils, depending on type and level of contaminants present, include chemical oxidation, soil stabilization, physical methods and bioremediation. Of all these methods used for remediation, bioremediation has received much attention of researchers because it is not only generally safe, but it is also an economic option in the treatment of a contaminated site (Erdogan and Karaca, 2011). Bioremediation is described as the use of microorganisms to destroy or immobilize waste materials (Shanahan, 2004). This process of detoxification targets the harmful chemicals by mineralization, transformation, or alteration (Shannon and Unterman, 1993). Bioremediation has been applied to treat crude oil-contaminated soils, wastewater, oil-contaminated water and refinery sludge (Mohammadi-Sichani et al., 2017; Benyahia, et al., 2005; Siles and Margesin, 2018; Paladino, et al, 2016, Varjani and Upasani, 2017). The communities of microbes which are exposed to hydrocarbons become adapted, exhibiting selective enrichment and genetic changes (Leahy and Colwell 1990; Atlas and Bartha, 1998). If the adapted microbial communities are biostimulated, they can respond to the presence of hydrocarbon pollutants within hours (Chikere et al., 2011). Hence in this study, chicken droppings were employed as biostimulants of indigenous microorganisms for the purpose of treating crude oilcontaminated soil.

\section{MATERIALS AND METHODS}

Collection of Poultry Droppings and Soil sample: Loamy soil samples collected were air-dried and sieved using a $2 \mathrm{~mm}$ mesh sieve and stored in polythene bags. The poultry droppings were obtained from the University of Benin agricultural farm. They were sun-dried for three days and thereafter pulverized before mixing with the soil. 
Bioremediation Process: $400 \mathrm{~g}$ each of the prepared soil samples were put into four equal-sized containers, and then contaminated with $20 \mathrm{ml}$ of crude oil and thoroughly mixed to ensure homogeneity. Thereafter, $20 \mathrm{~g}, 60 \mathrm{~g}$ and $100 \mathrm{~g}$ of the prepared poultry droppings were respectively mixed the oil-contaminated soil samples in the container A, B and C. The fourth container, D which was not mixed with poultry droppings served as the control. Table 1 shows the design of remediation experiments.

Table 1: Remediation Experimental Design

\begin{tabular}{|c|c|}
\hline $\begin{array}{c}\text { Sample } \\
\text { container }\end{array}$ & Treatment \\
\hline $\mathrm{A}$ & $400_{\mathrm{g}}$ soil $+20 \mathrm{ml}$ of crude oil $+20 \mathrm{~g}$ of PD \\
\hline B & $400 \mathrm{~g}$ soil $+20 \mathrm{ml}$ of crude oil $+60 \mathrm{~g}$ of $\mathrm{PD}$ \\
\hline $\mathrm{C}$ & $400 \mathrm{~g}$ soil $+20 \mathrm{ml}$ of crude oil $+100 \mathrm{~g}$ of PD \\
\hline $\mathrm{D}$ & $400_{\mathrm{g}}$ soil $+20 \mathrm{ml}$ of crude oil \\
\hline
\end{tabular}

Where PD stands for poultry droppings

Residual hydrocarbon contents (RHC) and $\mathrm{pH}$ of the samples were used as indicators of bioremediation. These parameters were monitored for a period of seven weeks.

Determination of $\mathrm{pH}$ and $\mathrm{RHC}$ : The $\mathrm{pH}$ values of the soil samples were measured in a soil-water suspension (1:5, w/v extraction ratio) according to the method described by Van Lierop and MacKenzie(1977).The residual hydrocarbon content ,RHC of the samples were determined using a method described by Osuji and Nwoye (2007).

A mixture of $5 \mathrm{~g}$ of contaminated soil and $50 \mathrm{ml}$ of xylene was vigorously shaken for twenty minutes. The mixture was then left to stand for 20 minutes, after which it was filtered with Whatmann filter paper (no 2). The RHC was calculated after reading the absorbance of the extract from the spectrophotometer at a wavelength of $425 \mathrm{~nm}$.

Modelling Studies with ANN: In this study, ANN analyses were performed using MATLAB Neural Network Toolbox.

The percentage degradations of sample THC were predicted by using the Feed forward prop. The architecture and the topology of the ANN consisted of an input layer with 7 neurons, 7 output layers with 7 neurons and one hidden layer and 6 output layers. The network was trained by the following learning algorithms: TRAINBFG (BFGS Quasi-Newton), TRAINBF, TRAINCGB (Conjugate Gradient with Powell/Beale Restarts), TRAINCGP (Polak-Ribiere Conjugate Gradient), TRAINCGF (Fletcher-Powell conjugate Gradient), TRAINSCG (Scaled Conjugate Gradient), TRAINLM (Levenberg-Marquardt), TRAINBR (Bayesian Regularization), TRAINGDX (Variable Learning Rate Gradient Descent), TRAINGDM (Gradient Descent with Momentum), TRAINGD (Gradient Descent), TRAINOSS (One step Secant), TRAINRP (Resilient Backpropagation), and TRRAINR (Resilient). Each ANN was trained using a stopping criterion of 1000 iterations. All data were divided into two parts as training and testing periods.

The first 20 sets of data were used for training of the ANN models, and the last 8 sets of data were employed for testing. The model performance indicators used in this study were coefficient of determination $\left(\mathrm{R}^{2}\right)$ and mean square error (MSE). A high $\mathrm{R}^{2}$ and low MSE values indicate a good model.

\section{RESULT AND DISCUSSION}

The variation of soil $\mathrm{pH}$ and $\mathrm{RHC}$ of the soil during the period of bioremediation are shown in Figures 1 and 2. From figure 1, it can be seen that sample A, sample B, sample C and sample D, show no significant increase in the $\mathrm{pH}$ value in the first four weeks. Their $\mathrm{pH}$ values were however observed to significantly increase from the fifth week to the seventh week.

The results also clearly indicate that the $\mathrm{pH}$ values of sample A to D were fairly acidic initially for the first five weeks, but increased to become basic from the sixth week.

The trend observed during the first four weeks may be due to microorganism initial adaptation phase to the environment and as such their activities would not be high enough to cause a significant change in the $\mathrm{pH}$ value, but the deviation from the fifth week can be attributed to the bio-degradation of the microbes responsible for the degradation of the hydrocarbon content through the utilization of nutrients, water and oxygen.

The result obtained was in line with the findings of Cunningham and Philp (2000), who obtained the optimum value of $\mathrm{pH}$ between the range of 6 and 8 while comparing bio-augmentation and biostimulation in ex-situ treatment of diesel-contaminated soil .

As shown elsewhere (Madhavi et al., 2012) both very low and very high $\mathrm{pH}$ values inhibit the microbial activities and as such it requires moderate or close to neural $\mathrm{pH}$ value for optimum function. Figure 2 shows the variation of the residual hydrocarbon content (RHC) of the sample with time. 


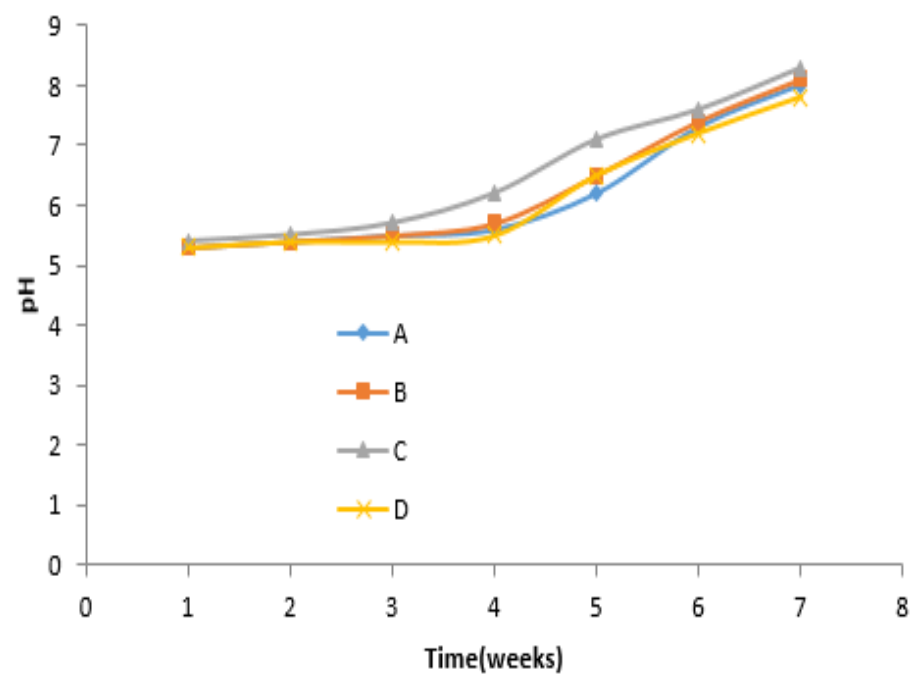

Fig 1: Variation of $\mathrm{pH}$ with time

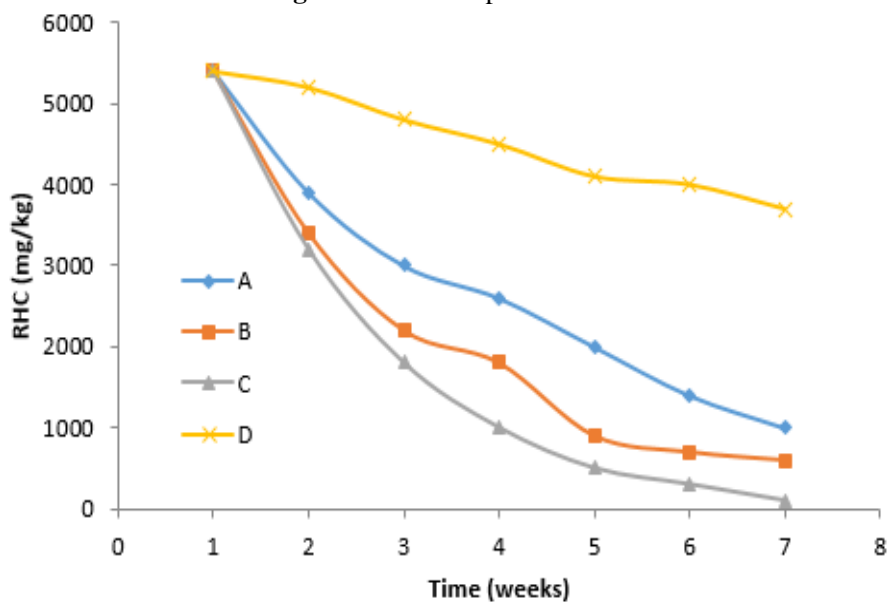

Fig 2: Variation of Residual Hydrocarbon Content (RHC) with time

Figure 2 shows the residual hydrocarbon content of the sample over a period of seven weeks. It was observed that increase in the amount of poultry droppings in the samples generally lead to a reduction in the RHC. It was also observed that the samples generally gave a decrease in RHC as time of remediation increased. It was however noticed that sample D (control) showed the least decease in RHC from week one to week seven in comparison with the other samples. It was also observed that sample $\mathrm{C}$ gave the highest reduction in RHC, followed by sample B and then sample A. This reduction in the RHC of the sample may be influenced directly by the amount of microorganism available for the bio-degradation. Hence, the observation that the sample with the highest amount of poultry manure, which also lead to increased microorganism availability, gave the highest reduction in RHC. This observation is in agreement with the trend observed in a previous related study (Onuoha et al., 2014). The models for RHC was simulated with MATLAB 2018a, using the feed forward prop architecture of the ANN.
The goodness of the model at predicting the experimental results obtained were assessed with mean square error (MSE) and the coefficient of determination $\left(\mathrm{R}^{2}\right)$ value. The smaller the value of MSE and the closer the $\mathrm{R}^{2}$ value is to unity, the better the model is able to predict the results. The MSE and $\mathrm{R}^{2}$ values obtained for each training algorithm for the percentage degradation of THC of the samples are shown in Table 2. In Table 2, the values of MSE and $\mathrm{R}^{2}$ range from $5.91 * 10^{6}$ to 0.00183 and -0.70381 to 0.99809 respectively for the training algorithms. A low value of the MSE is an good indication of a good model. It can be observed that the best and most suitable training algorithm is TRAINSCG since it has the least MSE value of 0.00183 . It is also observed that this training algorithm had the highest R-squared value of 0.99808 . This decision was based on the performance value of MSE, which gave the minimum deviation of the experimental data obtained to the predicted data. 
Table 2: $\mathrm{R}^{2}$ and MSE values of feed forward prop using different

\begin{tabular}{lcc}
\multicolumn{3}{c}{ training algorithm for RHC } \\
\hline Training & $\mathrm{R}^{2}$ value & $\begin{array}{l}\text { Mean } \\
\text { square } \\
\text { Algorithm }\end{array}$ \\
& & error \\
\hline TRAINBFG & 0.89082 & 191 \\
TRAINBR & -0.70381 & $5.91 * 10^{6}$ \\
TRAINCGB & 0.84489 & 1.47 \\
TRAINCGF & 0.93617 & 3.19 \\
TRAINCGP & 0.91201 & 15.8 \\
TRAINGD & 0.94787 & 1.59 \\
TRAINGDM & 0.85231 & 335 \\
TRAINGDA & 0.72051 & 292 \\
TRAINGDX & 0.88421 & 11.1 \\
TRAINLM & 0.84966 & 93.4 \\
TRAINOSS & 0.60074 & 22.4 \\
TRAINR & - & - \\
TRAINRP & 0.84936 & 1.75 \\
TRAINSCG & 0.99808 & 0.00183 \\
\hline
\end{tabular}

Conclusion: This study has shown that chicken droppings, which is safe, biodegradable and generally environmentally friendly is effective as a biostimulant for the remediation of crude oil-contaminated soil. This study showed that the soil amended with $100 \mathrm{~g}$ of poultry droppings gave the highest degradation of crude oil over a seven week period. The biodegration increased with increase in the amount of poultry droppings used to amend the crude oil-contaminated soil.

\section{REFERENCE}

Adams, GO; Fufeyin, PT; Okoro, SE; Ehinomen, I.(2015). Bioremediation, Biostimulation and Bioaugmention: A Review. Int. J. Environ. Bioremediat. Biodegrad. 3(1): 28-39.

Albert, ON; Amaratunga, D; Haigh, RP. (2018). Evaluation of impacts of Oil Spill Disaster on Communities and Its Influence on Restiveness in Niger Delta, Nigeria. Procedia Eng. 212: 10541061

Benyahia, F; Abdulkarim, M.; Zekri, A; Chaalal, O; Hasanain, H (2005). Bioremediation of crude oil contaminated soils a black art or an engineering challenge? Process Saf. Environ. Prot. 83: $364-$ 370 .

Chikere, CB; Okpokwasili, GC; Chikere, BO ( 2011).Monitoring of Microbial Hydrocarbon Remediation in the Soil. Biotech. 1:117-138

Cunningham, CJ; Philp, JC. (2000) Comparison of bioaugmentation and biostimulation in ex situ treatment of diesel contaminated soil. Land Contam. Reclamat. .8(4): 261-269.

Erdogan, EE; Karaca, A (2011). Bioremediation of crude oil polluted soils. Asian J. Biotechnol. 3: 206-213.

Leahy, JG; Colwell, RR. (1990) Microbial Degradation of hydrocarbons in the environment. Microbiol Rev. 53(3): 305-315.

Madhavi, MS; Naik, G; Mohini, MS; Dur, D. (2012). Review paper on - parameters affecting bioremediation. Int. J.Life Sci Pharma Res. 2(3): 77-80.

Mohammadi-Sichani,bM.; Assadi, M; Farazmand, A; Kianirad, M; Ahadi, A; Ghahderijani, HH (2017) Bioremediation of soil contaminated crude oil by Agaricomycetes, J. Environ. Health Sci. Eng. 15(8) 12-17.

Onuoha, SC; Chukwura, EI; Fatokun, K. (2014) Stimulated biodegradation of spent lubricating motor oil in soil amended with animal droppings. Am. J. Biol.Sci.2(1): 19-27.

Osuji, LC; Nwoye, I. (2007) An appraisal of the impact of petroleum hydrocarbons on soil fertility: the Owaza experience. Afr. J. Agric. Res. 2 (7): 318-324.

Paladino, G; Arrigoni, JP, Satti, P; Morelli, I; Mora, V; Laos, F (2016) Bioremediation of heaAvily hydrocarbon-contaminated drilling wastes by composting. Int. J. Environ. Sci. Technol. 13: 2227-2238.

Prasad, RG; Anuprakash, MV. (2016) Pollution Due to Oil Spills in Marine Environment And Control Measures. Environ. Sci. Cont. 10(9):1-8.

Shannon, MJ; Unterman, R. (1993) Evaluating bioremediation: distinguishing fact from fiction. Annu. Rev. Microbiol. 47:715-736

Siles, JA; Margesin, R. (2018) Insights into microbial communities mediating the bioremediation of hydrocarbon-contaminated soil from an Alpine former military site. Appl. Microbiol. Biotechnol. 102:4409-4421.

Van Lierop, WM; MacKenzie, AF. (1977) Soil pH Measurement and its Application to Organic Soils. Can. J. Soil. Sci. 57:55-64.

Varjani, SJ;Upasani, VN. (2017) A new look on factors affecting microbial degradation of petroleum hydrocarbon pollutants. Int. Biodeter Biodegr. 120: 71-83 